\title{
Cardinal temperatures for the leaf development of Corymbia citriodora and Eucalyptus urophylla seedlings
}

\author{
Cleverson Henrique de Freitas ${ }^{(1)}$, Fabrina Bolzan Martins ${ }^{(1)}$ and Marcel Carvalho Abreu(1)
} (1)Universidade Federal de Itajubá, Instituto de Recursos Naturais, Avenida BPS, no 1.303, Pinheirinho, CEP $37500-903$ Itajubá, MG, Brazil.
E-mail: sonhfreitas@gmail.com, fabrina@unifei.edu.br, marcelc.abreu@gmail.com

\begin{abstract}
The objective of this work was to estimate cardinal temperatures and phyllochron for the leaf development of the eucalyptus species Corymbia citriodora and Eucalyptus urophylla, in the seedling phase. A field experiment was carried out in a completely randomized design, in a $2 \times 11$ factorial arrangement, with the two eucalyptus species, 11 sowing dates, and five replicates, in the municipality of Itajubá, in the state of Minas Gerais, Brazil. The cardinal temperatures - base, optimum, and maximum - for leaf development were, respectively, $8.7,17.1$, and $41.3^{\circ} \mathrm{C}$, for C. citriodora, and $11.5,17.1$, and $40.5^{\circ} \mathrm{C}$ for E. urophylla. The phyllochron of $C$. citriodora was $62.95^{\circ} \mathrm{C}$ day per leaf, and that of E. urophylla was $46.03^{\circ} \mathrm{C}$ day per leaf, which indicates that $E$. urophylla requires less energy accumulation than $C$. citriodora for leaf emission in the main stem.
\end{abstract}

Index terms: air temperature, leaf emission rate, phyllochron, seedling quality, thermal requirement.

\section{Temperaturas cardinais para o desenvolvimento foliar de mudas de Corymbia citriodora e Eucalyptus urophylla}

\begin{abstract}
Resumo - O objetivo deste trabalho foi estimar as temperaturas cardinais e o filocrono para o desenvolvimento foliar das espécies de eucalipto Corymbia citriodora e Eucalyptus urophylla, durante a fase de muda. Um experimento de campo foi realizado em delineamento inteiramente casualizado, em arranjo fatorial $2 \times 11$, com as duas espécies de eucalipto, 11 épocas de semeadura e cinco repetições, em Itajubá, MG. As temperaturas cardinais - basal inferior, ótima e basal superior - para o desenvolvimento foliar foram, respectivamente, $8,7,17,1$ e $41,3^{\circ} \mathrm{C}$, para C. citriodora, e $11,5,17,1$ e $40,5^{\circ} \mathrm{C}$, para E. urophylla. O filocrono de C. citriodora foi de $62,95^{\circ} \mathrm{C}$ dia por folha, e o de E. urophylla, de $46,03^{\circ} \mathrm{C}$ dia por folha, o que é indício de que E. urophylla necessita de menor acúmulo energético do que C. citriodora para a emissão de folhas na haste principal.

Termos para indexação: temperatura do ar, taxa de emissão foliar, filocrono, qualidade de mudas, necessidade térmica.
\end{abstract}

\section{Introduction}

Air temperature has a direct effect on the physiological processes of plants, moderating the biochemical reactions of photosynthesis and photorespiration, besides regulating the enzymatic activities, the transportation and translocation speed of solutes, and the balance between transpiration and soil water consumption. These processes directly affect the plant development rate (Soltani \& Sinclair, 2012; Callejas et al., 2014), with emphasis on leaf emission rate, known as phyllochron (Erpen et al., 2013), and on yield. Air temperature is considered the meteorological element that most affects the development of annual and perennial plants (Rosa et al., 2009; Lisboa et al., 2012).
Mathematically, the daily accumulation of available energy can be determined by linear functions, such as that of the phyllochron, or nonlinear functions, which are widely used in annual and perennial crop development models (Streck et al., 2011; Callejas et al., 2014; Martins et al., 2014). Regardless of the function type, they require the inclusion of cardinal temperatures - base ( $\mathrm{Tb}$ ), optimum (Tot), and maximum (TB) -, that represent the thermal limits within which plants develop properly (Müller et al., 2009; Rosa et al., 2009). The base and maximum temperatures ( $\mathrm{Tb}$ and $\mathrm{TB}$ ) represent, respectively, the temperatures below or above which the plant development is null or negligible (Müller et al., 2009; Souza \& Martins, 2014). The optimum temperature 
represents the temperature at which plant development is maximum. The cardinal temperatures vary between species, genotypes of the same species and also according to the evaluated period of development (Lago et al., 2009).

In most cases, cardinal temperatures are determined by statistical methods, based on data of phenological observations and average air temperature (Lago et al., 2009; Souza \& Martins, 2014). For the Tb estimation, there is a variety of methods, among which the most used ones are: standard deviation in days and degreedays, the coefficient of variation in days and degreedays, regression coefficient, X-intercept, and the smallest value for the mean square error (Yang et al., 1995; Sinclair et al., 2004). In order to estimate the optimum temperature, plants should be subjected to the best developmental conditions, which is usually done under controlled experimental conditions (Soltani \& Sinclair, 2012) using of growth rooms, which are expensive. However, for the estimation of $\mathrm{TB}$, the number of methodologies is reduced and, generally, they have a high cost of determination. Moreover, these temperatures are hardly reached during the development cycle in the field (Lima \& Silva, 2008; Souza \& Martins, 2014).

The knowledge of cardinal temperatures and phyllochron values is important to optimize the management strategies, to improve seedling production and quality, to support selection and breeding programs, and to choose species that are more adapted to the climatic conditions of the growing location (Müller et al., 2009; Martins et al., 2012). Studies of this nature are widely carried out on agricultural (Sinclair et al., 2004; Lago et al., 2009; Lucas et al., 2012), ornamental, and medicinal crops (Luz et al., 2012), but are still scarce on perennial crops (Lima \& Silva, 2008; Callejas et al., 2014; Souza \& Martins, 2014), especially forest species, even on those of great economic interest, such as eucalyptus (Martins et al., 2007).

The increasing demand for products from eucalyptus (Abreu et al., 2015), as well as the importance of producing and using good quality seedlings for success in field establishment (Martins et al., 2007), makes this information important for increasing the efficiency of this crop chain of production.

The objective of this work was to estimate cardinal temperatures and phyllochron for leaf development of the eucalyptus species Corymbia citriodora and Eucalyptus urophylla, in the seedling phase.

\section{Materials and Methods}

The experiment was carried out in the experimental area of the Universidade Federal de Itajubá, in the municipality of Itajubá, in the state of Minas Gerais, Brazil. According to Köppen-Geiger's classification, the climate of the region is Cwa, tropical of altitude, with dry winters, and hot and rainy summers (Abreu et al., 2015).

The experiment was conducted in a completely randomized design, in a 2x11 factorial arrangement, with two eucalyptus species, Corymbia citriodora (Hook) K. D. Hill \& L. A. S. Johnson and Eucalyptus urophylla S. T. Blake, 11 sowing dates, and 5 replicates, totalizing 110 experimental units (EU). Each EU contained two plants, grown in $8 \mathrm{~L}$ pots filled with soil of the A horizon of a Latossolo Vermelho distrófico típico (Santos et al., 2013), a Rhodic Hapludox.

The chemical and physical analyses of the soil were carried out, with subsequent correction of acidity and fertility by the application of $10.18 \mathrm{~g}$ of simple superphosphate, $0.31 \mathrm{~g}$ of potassium chloride, and $0.20 \mathrm{~g}$ of ammonium sulfate, in each pot, in addition to liming with $12.32 \mathrm{~g}$ of $\mathrm{CaCO}_{3}$, according to Ribeiro et al. (1999).

The pots were coated with newsprint paper to prevent substrate heating by the absorption of solar radiation, which could be a source of experimental error (Martins et al., 2007). Daily and regular watering was carried out in the evening period, aimimg at leaving the soil close to saturation in each pot, in order to eliminate the possibility of water stress occurrence, which could affect leaf emission. Watering was not performed on rainy days.

Sowing was performed at 30-day intervals, in order to expose plants to different meteorological conditions (Table 1) during their development (Müller et al., 2009; Rosa et al., 2009). For the estimation of the optimum temperature, 11 sowing dates were used, while for $\mathrm{Tb}$ estimation, only the first four sowing dates were used, since they included the lowest air temperatures (Sinclair et al., 2004). Similarly, only the sowing dates with the highest air temperatures were used in the estimation of TB (Lima \& Silva, 2008). 
Leaf development was quantified by the number of leaves accumulated in the main stem (NL) during the seedling phase, which began when plants reached $50 \%$ of the emergence, and ended when each experimental unit reached an average of 20 accumulated leaves (Martins et al., 2007; Abreu et al., 2015). The axillary shoots were removed, in order to keep only the main stem growing. The number of leaves was counted once a week, when each leaf was at least $1.0 \mathrm{~cm}$ length (Martins et al., 2012).

Daily data of average air temperature were collected from the automatic meteorological station of the Universidade Federal de Itajubá, located $500 \mathrm{~m}$ apart from the experimental area.

In order to estimate $\mathrm{Tb}$, the methodology of the smallest mean square error (MSE) (Sinclair et al., 2004) was used, which was chosen for its precision and simplicity (Martins et al., 2012). For each species and sowing date (E1 to E4), simple linear regressions were carried out between the mean NL, given by the arithmetic mean of the NL of the five experimental units, and the accumulated thermal time (TT, ${ }^{\circ} \mathrm{C}$ day), obtained by the expression

$$
\mathrm{TT}=\sum_{\mathrm{i}=1}^{\mathrm{n}} \mathrm{T}_{\mathrm{med}}-\mathrm{Tb}, \quad \text { if } \mathrm{T}_{\text {med }}<\mathrm{Tb}, \mathrm{T}_{\text {med }}=\mathrm{Tb}
$$

Table 1. Sowing date and seedling emergence periods ${ }^{(1)}$ of Corymbia citriodora and Eucalyptus urophylla.

\begin{tabular}{lcc}
\hline Sowing date & \multicolumn{2}{c}{ Seedling emergence } \\
\cline { 2 - 3 } & C. citriodora & E. urophylla \\
\hline E1, 04/04/2014 & $04 / 22 / 2014$ & $04 / 22 / 2014$ \\
E2, 05/05/2014 & $05 / 15 / 2014$ & $05 / 15 / 2014$ \\
E3, 06/02/2014 & $06 / 26 / 2014$ & $06 / 26 / 2014$ \\
E4, 07/02/2014 & $07 / 30 / 2014$ & $07 / 30 / 2014$ \\
E5, 08/19/2014 & $09 / 07 / 2014$ & $09 / 07 / 2014$ \\
E6, 09/16/2014 & $09 / 30 / 2014$ & $10 / 02 / 2014$ \\
E7, 10/15/2014 & $10 / 29 / 2014$ & $10 / 29 / 2014$ \\
E8, 11/18/2014 & $12 / 03 / 2014$ & $11 / 30 / 2014$ \\
E9, 12/18/2014 & $12 / 28 / 2014$ & $12 / 28 / 2014$ \\
E10, 01/21/2015 & $02 / 05 / 2015$ & $-(2)$ \\
E11, 02/20/2015 & $02 / 27 / 2015$ & $02 / 27 / 2015$ \\
\hline
\end{tabular}

${ }^{(1)}$ The emergence date was considered when $50 \%$ of the seedlings were above the soil level. (2)All experimental units of E. urophylla were lost in the E10 sowing date. in which: $\mathrm{T}_{\text {med }}$ is the medium air temperature, obtained by the arithmetic mean of hourly temperatures from the automatic weather station $\left({ }^{\circ} \mathrm{C}\right)$; $\mathrm{Tb}$ is the base temperature $\left({ }^{\circ} \mathrm{C}\right)$; ' $\mathrm{i}$ ' is the date of emergence; and ' $\mathrm{n}$ ' is the end date of the seedling phase. For the calculation of TT, a Tb series that varied from 0 to $20^{\circ} \mathrm{C}$ was used at $0.5^{\circ} \mathrm{C}$ intervals (Lucas et al., 2012). The $\mathrm{Tb}$ value for each sowing date was the one that showed the lowest MSE value of the linear regressions (Martins et al., 2012); while the Tb value, for each species, was obtained by the arithmetic mean of the $\mathrm{Tb}$ values observed at different sowing dates.

To estimate TB, the methodology modified by Lima \& Silva (2008) was used with the following expressions:

Case 1: TB $>$ Tmed $>$ Tb.

$$
\begin{aligned}
& \mathrm{A}=\mathrm{N}_{2} \cdot \mathrm{TM}_{1} \cdot \mathrm{TM}_{2}-\mathrm{N}_{2} \cdot \mathrm{TM}_{2} \cdot \mathrm{Tm}_{1} \\
& \mathrm{~B}=-\mathrm{N}_{1} \cdot \mathrm{TM}_{1} \cdot \mathrm{TM}_{2}+\mathrm{N}_{1} \cdot \mathrm{TM}_{1} \cdot \mathrm{Tm}_{2} \\
& \mathrm{C}=\left(-\mathrm{TM}_{1}+\mathrm{Tm}_{1}\right) \cdot\left(-\mathrm{TM}_{2}+\mathrm{Tm}_{2}\right) \\
& \mathrm{D}=\mathrm{N}_{1} \cdot \mathrm{Tm}_{2}^{2} \cdot \mathrm{N}_{2}-2 \cdot \mathrm{Tm}_{2} \cdot \mathrm{N}_{1} \cdot \mathrm{N}_{2} \cdot \mathrm{Tb}-\mathrm{Tm}_{2} \cdot \mathrm{Tm}_{1} \cdot \mathrm{N}_{1}{ }^{2} \\
& \mathrm{E}=-\mathrm{Tm}_{2} \cdot \mathrm{TM}_{1} \cdot \mathrm{N}_{1}{ }^{2}+\mathrm{N}_{2}{ }^{2} \cdot \mathrm{TM}_{1} \cdot \mathrm{Tm}_{2}-\mathrm{Tm}_{1} \cdot \mathrm{N}_{2}{ }^{2} \cdot \mathrm{Tm}_{2}+2 \cdot \mathrm{Tm}_{2} \cdot \mathrm{N}_{2}{ }^{2} \cdot \mathrm{Tb} \\
& \mathrm{F}=\mathrm{Tm}_{1} \cdot \mathrm{N}_{1}^{2} \cdot \mathrm{TM}_{2}-2 \cdot \mathrm{N}_{2}{ }^{2} \cdot \mathrm{TM}_{1} \cdot \mathrm{Tb}-2 \cdot \mathrm{N}_{1}{ }^{2} \cdot \mathrm{TM}_{2} \cdot \mathrm{Tb} \\
& \mathrm{G}=\mathrm{TM}_{1} \cdot \mathrm{N}_{1}{ }^{2} \cdot \mathrm{TM}_{2}+\mathrm{Tm}_{1}{ }^{2} \cdot \mathrm{N}_{2} \cdot \mathrm{N}_{1}-2 \cdot \mathrm{Tm} \mathrm{m}_{1} \cdot \mathrm{N}_{2} \cdot \mathrm{N}_{1} \cdot \mathrm{Tb} \\
& \mathrm{H}=2 \cdot \mathrm{Tm}_{1} \cdot \mathrm{N}_{2}{ }^{2} \cdot \mathrm{Tb}+2 \cdot \mathrm{N}_{1} \cdot \mathrm{TM}_{2} \cdot \mathrm{N}_{2} \cdot \mathrm{Tb}+2 \cdot \mathrm{N}_{2} \cdot \mathrm{TM}_{1} \cdot \mathrm{N}_{1} \cdot \mathrm{Tb} \\
& \mathrm{I}=-2 \cdot \mathrm{N}_{2} \cdot \mathrm{TM}_{1} \cdot \mathrm{N}_{1} \cdot \mathrm{TM}_{2}+\mathrm{N}_{2}{ }^{2} \cdot \mathrm{TM}_{1} \cdot \mathrm{TM}_{2}-\mathrm{Tm}_{1} \cdot \mathrm{N}_{2}^{2} \cdot \mathrm{TM}_{2} \\
& \mathrm{~J}=-\mathrm{N}_{1} \cdot \mathrm{TM}_{2}+\mathrm{N}_{1} \cdot \mathrm{Tm}_{2}+\mathrm{N}_{2} \cdot \mathrm{TM}_{1}-\mathrm{N}_{2} \cdot \mathrm{Tm}_{1} \\
& \mathrm{~TB}=[\mathrm{A}+\mathrm{B} \pm \sqrt{\mathrm{C} \times(\mathrm{D}+\mathrm{E}+\mathrm{F}+\mathrm{G}+\mathrm{H}+\mathrm{I})}] / \mathrm{J}
\end{aligned}
$$

Case 2: $\mathrm{TB}>\mathrm{Tb}>$ Tmed. For calculation purposes, the highest $\mathrm{TB}$ value is considered:

$$
\begin{aligned}
& \mathrm{A}=-\mathrm{N}_{1} \cdot \mathrm{Tb} \cdot \mathrm{TM}_{2}+\mathrm{N}_{1} \cdot \mathrm{Tb} \cdot \mathrm{Tm}_{2}+\mathrm{N}_{2} \cdot \mathrm{TM}_{1} \cdot \mathrm{Tb} \\
& \mathrm{B}=-\mathrm{N}_{2} \cdot \mathrm{Tm} \mathrm{m}_{1} \cdot \mathrm{Tb}-2 \cdot \mathrm{N}_{2} \cdot \mathrm{TM}_{1} \cdot \mathrm{TM}_{2}+2 \cdot \mathrm{N}_{2} \cdot \mathrm{TM}_{2} \cdot \mathrm{Tm}_{1} \\
& \mathrm{C}=2 \cdot \mathrm{N}_{1} \cdot \mathrm{TM}_{1} \cdot \mathrm{TM}_{2}-2 \cdot \mathrm{N}_{1} \cdot \mathrm{TM}_{1} \cdot \mathrm{Tm}_{2} \\
& \mathrm{D}=\mathrm{N}_{1} \cdot \mathrm{TM}_{2}-\mathrm{N}_{1} \cdot \mathrm{Tm}_{2}-\mathrm{N}_{2} \cdot \mathrm{TM}_{1}+\mathrm{N}_{2} \cdot \mathrm{Tm}_{1} \\
& \mathrm{~TB}=(\mathrm{A}+\mathrm{B}+\mathrm{C}) / \mathrm{D}
\end{aligned}
$$

in which: $\mathrm{N}_{1}$ and $\mathrm{N}_{2}$ are the number of days of seedling production cycle - ranging from $50 \%$ of emergence to the final seedling phase - for the two sowing dates, respectively, with the highest average of air temperature; $\mathrm{TM}_{1}$ and $\mathrm{TM}_{2}$ are the maximum air temperatures of the two sowing dates; $\mathrm{Tm}_{1}$ and $\mathrm{Tm}_{2}$ are minimum air temperatures.

In order to estimate the optimum temperature, the methodology proposed by Lisboa et al. (2012) was

Pesq. agropec. bras., Brasília, v.52, n.5, p.283-292, maio 2017 DOI: $10.1590 / \mathrm{S} 0100-204 \mathrm{X} 2017000500001$ 
used, which is based on the arithmetic mean of air temperature of the sowing date with the highest leaf development and, consequently, lowest phyllochron. For this, the phyllochron was determined for each species and experimental unit, during the sowing dates, by the inverse of the linear regression coefficient between NL and TT, from the emergence date, using the $\mathrm{Tb}$ value estimated by the MSE.

To verify the normality of the data, the ShapiroWilk test was used, at 5\% probability. Data which did not follow normality were transformed by $\operatorname{Ln}(\mathrm{x})$. The phyllochron values were subjected to the analysis of variance, in order to evaluate the effect of the sources of variation (species and sowing dates); and the means were compared by the Scott-Knott's test, at $5 \%$ probability. The tests were carried out with the statistical Sisvar software, version 5.3 (Ferreira, 2011).

\section{Results and Discussion}

Plants were subjected to wide temperature oscillations during the evaluated 11 sowing dates (Table 2). Air temperature varied between $3.8^{\circ} \mathrm{C}$ - absolute minimum value of temperature, observed in the sowing dates $\mathrm{E} 2, \mathrm{E} 3$, and $\mathrm{E} 4-$ and $35.7^{\circ} \mathrm{C}$, absolute maximum temperature, observed during the sowing dates E3 to E9. These different meteorological conditions affected leaf emission speed and development, which are important in studies of development and plant growth (Rosa et al., 2009), and for the estimation of cardinal temperatures (Lima \& Silva, 2008; Souza \& Martins, 2014).

The difference in the meteorological conditions during the 11 sowing dates also affected the seedling development, whose duration showed a tendency of reduction during periods with higher temperatures, and a tendency of increase during periods with lower temperatures. The presence of an inverse relationship between air temperature and duration of the seedling phase justifies the choice of the first four seasons (April, May, June, and July) for the Tb estimation. The same tendency was observed by Luz et al. (2012) in canola, and by Souza \& Martins (2014) in olive cultivars. However, E7 showed a long duration, even in high air temperature conditions, which would justify the choice of this period for the TB estimation, while E8 was chosen due to the higher mean air temperature value, in relation to the other periods. It is known that environmental factors, such as extreme temperatures, water and nutritional stress, and photoperiod affect the leaf emission rate (Rosa et al., 2009). In this sense,

Table 2. Air temperature characterization ${ }^{(1)}$ during the eleven sowing dates of Corymbia citriodora and Eucalyptus urophylla, and the seedling phase duration ${ }^{(2)}$ for each period.

\begin{tabular}{|c|c|c|c|c|c|c|c|c|}
\hline \multirow{3}{*}{$\begin{array}{l}\text { Sowing } \\
\text { date }\end{array}$} & \multicolumn{4}{|c|}{ Corymbia citriodora } & \multicolumn{4}{|c|}{ Eucalyptus urophylla } \\
\hline & \multicolumn{3}{|c|}{ Temperature $\left({ }^{\circ} \mathrm{C}\right)$} & \multirow{2}{*}{$\begin{array}{l}\text { Seedling phase } \\
\text { duration (days)' }\end{array}$} & \multicolumn{3}{|c|}{ Temperature $\left({ }^{\circ} \mathrm{C}\right)$} & \multirow{2}{*}{$\begin{array}{l}\text { Seedling phase } \\
\text { duration (days) }\end{array}$} \\
\hline & Medium & Maximum & Minimum & & Medium & Maximum & Minimum & \\
\hline E1 & 17.1 & 20.2 & 13.9 & 97 & 17.1 & 20.2 & 13.9 & 97 \\
\hline E2 & 18.5 & 26.5 & 13.9 & 166 & 18.4 & 26.5 & 13.9 & 159 \\
\hline E3 & 18.8 & 26.5 & 14.0 & 117 & 18.8 & 26.5 & 14.0 & 117 \\
\hline E4 & 20.2 & 26.5 & 14.0 & 97 & 20.4 & 26.5 & 14.0 & 104 \\
\hline E5 & 22.3 & 26.5 & 15.6 & 122 & 22.2 & 26.5 & 15.6 & 124 \\
\hline E6 & 22.7 & 26.5 & 15.6 & 99 & 22.7 & 26.5 & 15.6 & 99 \\
\hline E7 & 23.4 & 27.3 & 19.1 & 105 & 23.4 & 27.3 & 19.4 & 114 \\
\hline E8 & 23.6 & 27.3 & 19.1 & 79 & 23.6 & 27.3 & 19.1 & 79 \\
\hline E9 & 23.2 & 27.3 & 19.1 & 89 & 23.2 & 27.3 & 19.1 & 89 \\
\hline E10 & 20.9 & 26.1 & 15.2 & 116 & $-^{(3)}$ & - & - & - \\
\hline E11 & 20.0 & 24.7 & 15.3 & 105 & 20.3 & 24.7 & 15.3 & 94 \\
\hline
\end{tabular}

(1)Values obtained by arithmetic averages of maximum, medium and minimum air temperatures. ${ }^{(2)}$ Period extending from the emergence to the end of seedling phase, which occurred when the accumulated leaves of the main stem achieved an average of 20 leaves. ${ }^{(3)}$ All experimental units of E. urophylla were lost in the E10 sowing date. 
despite the regular and constant watering, it should be noted that, during the period of conduction of the experiment, the cumulative rainfall was $1,286.8 \mathrm{~mm}$, which is below the climatological average of 1,440 $\mathrm{mm}$. In addition, elevated temperatures occurred, mainly during the E7 and E8 (Table 2). However, this variation of the meteorological conditions, mainly for air temperature, is desirable and a premise for this type of study (Lago et al., 2009; Rosa et al., 2009; Martins et al., 2012).

For $\mathrm{Tb}$ estimation, all regressions between the mean NL and the TT showed high values of the adjusted coefficient of determination ( $\mathrm{R}^{2} \mathrm{adj}$ ) - above 0.897 for C. citriodora, and 0.845 for E. urophylla; low MSE values - lower than 1.426 and 1.961, respectively; and significant angular and linear coefficients $(\mathrm{p} \leq 0.05)$. These characteristics are desirable for $\mathrm{Tb}$ estimation by the lower MSE values method (Sinclair et al., 2004; Martins et al., 2007).

The evaluated species and sowing dates varied for $\mathrm{Tb}$ values (Figure 1), which was also observed by Lucas et al. (2012). For C. citriodora, in E1, the lowest value of $\mathrm{MSE}(0.2487)$ was for $\mathrm{Tb}=6^{\circ} \mathrm{C}$; in $\mathrm{E} 2$, the lowest value of $\mathrm{MSE}(0.6073)$ was for $\mathrm{Tb}=0^{\circ} \mathrm{C}$; in $\mathrm{E} 3$, the lowest value of MSE $(0.1535)$ was for $\mathrm{Tb}=11.5^{\circ} \mathrm{C}$; and in E4, the lowest value of MSE (0.3482) was for $\mathrm{Tb}=0^{\circ} \mathrm{C}$. However, from a biological point of view, the value of $\mathrm{Tb}=0^{\circ} \mathrm{C}$ is not considered realistic and, therefore, it was not considered when the average $\mathrm{Tb}$ of the species was obtained (Lago et al., 2009; Martins et al., 2012). Thus, the value of Tb obtained for C. citriodora was $8.7^{\circ} \mathrm{C}$, using the arithmetic mean of the $\mathrm{Tb}$ values of $\mathrm{E} 1$ and $\mathrm{E} 3$, except for $\mathrm{E} 2$ and $\mathrm{E} 4$, which showed $\mathrm{Tb}=0^{\circ} \mathrm{C}$.

The sowing dates E2 and E4 were also not used for the estimation of $\mathrm{Tb}$ for E. urophylla (Figure 1), as the lower values of MSE $(E 2=0.9400$, and E4 $=0.6327)$ were obtained for $\mathrm{Tb}=0^{\circ} \mathrm{C}$. The sowing dates $\mathrm{E} 1$ and E3 showed the lowest values of MSE (0.2541 and 0.5108 , respectively) for $\mathrm{Tb}=11.5^{\circ} \mathrm{C}$, and this value was considered as the $\mathrm{Tb}$ of the species. These results indicate advantages in the production of seedlings of C. citriodora in relation to E. urophylla, for winter sowing, when the temperatures are lower.

The $\mathrm{Tb}$ varies among species, genotypes of the same species, and usually varies due to the stage of

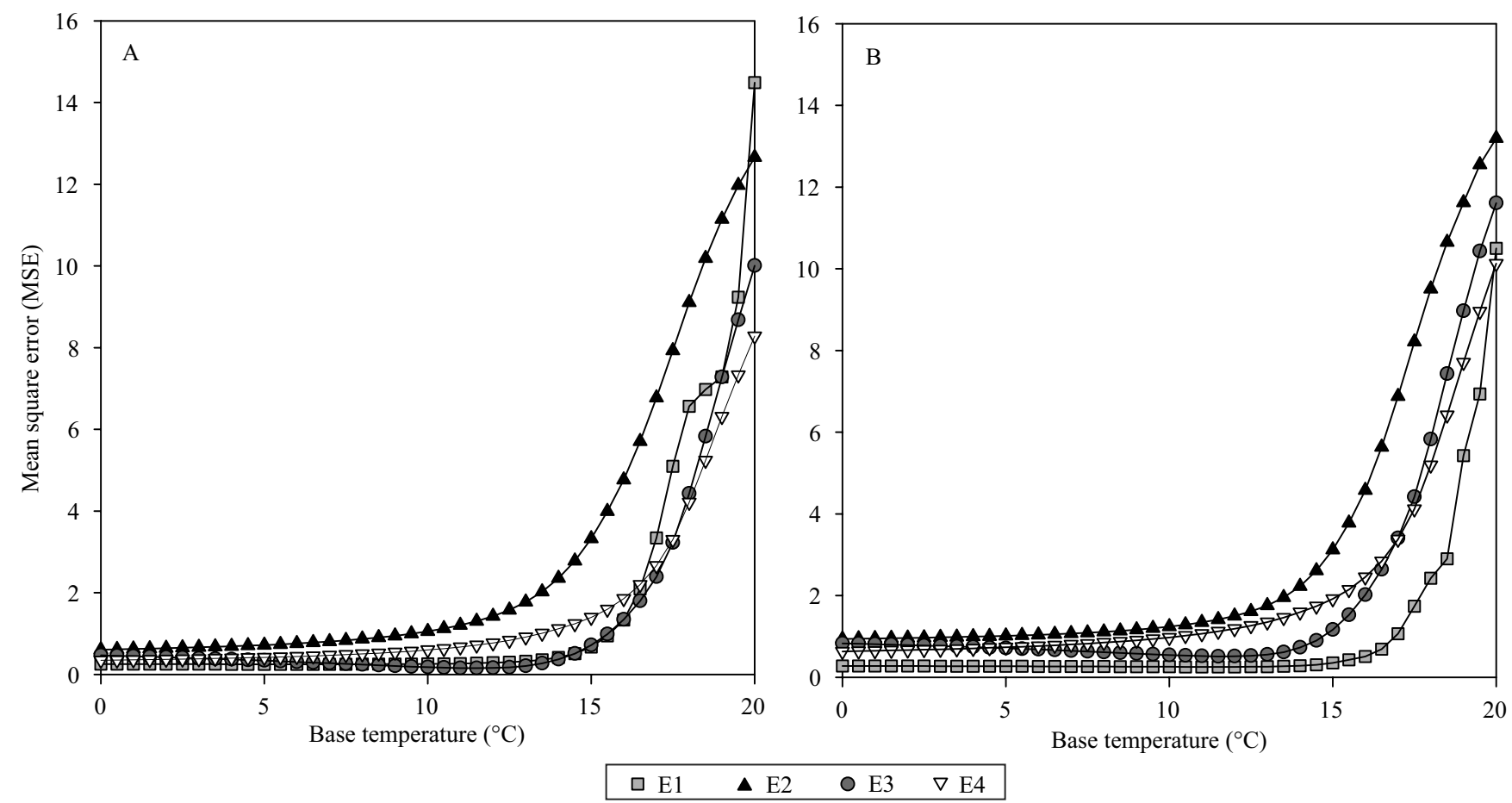

Figure 1. Mean square error (MSE) of the regression between the number of accumulated leaves in the main stem and the accumulated thermal time, in the four sowing dates with lower values of medium air temperature, with the use of different values of base temperature for: A, Corymbia citriodora; and B, Eucalyptus urophylla. 
development (Yang et al., 1995; Lago et al., 2009) and the studied metabolic process (Soltani \& Sinclair, 2012). In the present study, the values of Tb estimated for Corymbia citriodora $\left(8.7^{\circ} \mathrm{C}\right)$ were close to the values reported for leaf development of other perennial crops, such as: E. saligna, $8.0^{\circ} \mathrm{C}$ (Martins et al., 2007); Acer pensylvanicum, Acer rubrum, and Betula popifolia, $7.5^{\circ} \mathrm{C}$ (Chiang \& Brown, 2007); and the olive cultivar Olea europaea 'Grappolo', 9.6 $6^{\circ} \mathrm{C}$ (Souza \& Martins, 2014). As to growth (Almeida \& Sands, 2016), leaf area index (Battaglia et al., 1996), and photosynthetic process (Sands \& Landsberg, 2002) of Eucalyptus globulus, $\mathrm{Tb}$ values of $8.5,7.8$, and $7.5^{\circ} \mathrm{C}$ were observed, respectively. Regarding the vegetative development of annual crops, close values of $\mathrm{Tb}$ were observed, as from 7.0 to $8.0^{\circ} \mathrm{C}$, in ryegrass (Müller et al., 2009), and 8.0 to $10.9^{\circ} \mathrm{C}$ in irrigated rice (Lago et al., 2009).

The $\mathrm{Tb}$ value of $11.5^{\circ} \mathrm{C}$ in E. urophylla is close to the one reported for leaf development of E. grandis $\left(10.0^{\circ} \mathrm{C}\right)$ (Martins et al., 2007) and other perennial crops, such as: Quercus alba and Populus tremuloides, with $10.0^{\circ} \mathrm{C}$ (Chiang \& Brown, 2007); the olive cultivars Arbequina, with $10.5^{\circ} \mathrm{C}$, and MGS ASC315, with $11.0^{\circ} \mathrm{C}$ (Martins et al., 2012); mango, with $10.6^{\circ} \mathrm{C}$ (Callejas et al., 2014); and arabica coffee cultivars Rubi MG-1192 and Acaiá Cerrado MG-1474, with $12.9^{\circ} \mathrm{C}$ (Lima \& Silva, 2008). Close $\mathrm{Tb}$ values were also reported for some annual crops, such as canola hybrids, with 9.9 and $10.0^{\circ} \mathrm{C}$ (Luz et al., 2012), and red rice biotypes, with 9.9 and $10.5^{\circ} \mathrm{C}$ (Lago et al., 2009).

The estimated TB values was obtained according to "case 1", where TB $>$ Tmed $>$ Tb. For $C$. citriodora, the TB value observed was $41.3^{\circ} \mathrm{C}$ and, for E. urophylla, $40.5^{\circ} \mathrm{C}$. According to the results, C. citriodora shows tolerance to higher temperatures, with a TB slightly higher than that for E. urophylla, during the seedling phase, besides the higher tolerance to lower temperatures $\left(\mathrm{Tb}=8.7^{\circ} \mathrm{C}\right.$, compared to $11.5^{\circ} \mathrm{C}$ obtained for E. urophylla). The effect of air temperature above TB can induce significant anomalies on the eucalyptus growth and development, such as floral abortion, reduction of leaf emission, excess of lateral branches, loss of apical dominance and reduction of survival rate (Paton, 1980). The TB values obtained in the present study are realistic, from the biological point of view, and are similar to the values obtained for E. globulus and Pinus ponderosa $\left(40.0^{\circ} \mathrm{C}\right)$ (Sands \&
Landsberg, 2002; Landsberg et al., 2003) and higher than those reported for E. grandis $\left(36.0^{\circ} \mathrm{C}\right)$ and $E$. saligna $\left(35.0^{\circ} \mathrm{C}\right)$ (Martins \& Streck, 2007). However, lower TB values are normally observed in perennial or annual crops, such as wheat, rice-red biotypes $\left(35.0^{\circ} \mathrm{C}\right)$ (Rosa et al., 2009; Streck et al., 2011), coffee $\left(32.4^{\circ} \mathrm{C}\right)$ (Lima \& Silva, 2008), and cashew $\left(30.7^{\circ} \mathrm{C}\right)$ (Matos et al., 2014). Due to the large variation in TB values for annual crops, as presented in the literature, it is possible to infer that perennial crops are more tolerant, and therefore more adapted to higher air temperatures.

Optimum temperatures were obtained by linear regressions, which resulted in high $\mathrm{R}^{2}$ adjusted values (above 0.864), low MSE (lower than 3.847), significant coefficients $(\mathrm{p} \leq 0.05)$, and linearity between leaf development and air temperature (Figures 2 and 3). In addition, they indicated that air temperature strongly affects leaf emission in the two evaluated species, and that their estimation is possible with the use of the proposed methodology by Lisboa et al. (2012).

The variance analysis for phyllochron showed a significant effect of both sources of variation $(p \leq 0.05)$, without a significant interaction $(\mathrm{p}=0.0940)$. The phyllochron mean values were $62.95 \pm 15.15^{\circ} \mathrm{C}$ day per leaf, in C. citriodora, and $46.03 \pm 10.89^{\circ} \mathrm{C}$ day per leaf in E. urophylla. Therefore, C. citriodora demands greater energy accumulation for the emission of a leaf in the main stem, in comparison to E. urophylla. This result may have occurred due to the lower $\mathrm{Tb}$ value obtained for C. citriodora $\left(8.7^{\circ} \mathrm{C}\right)$, which resulted in a higher thermal accumulation for the species at the same air temperature.

In the field, E. urophylla showed a greater leaf development, higher emergence speed, better seedling uniformity, and faster leaf emission than C. citriodora. Different phyllochron values were reported for other eucalyptus species, such as $E$. grandis $\left(32.0^{\circ} \mathrm{C}\right.$ day per leaf) and E. saligna $\left(30.7^{\circ} \mathrm{C}\right.$ day per leaf) (Martins et al., 2007), for the olive cultivars Arbequina $\left(21.7^{\circ} \mathrm{C}\right.$ day per leaf) and MGS ASC315 $\left(41.6^{\circ} \mathrm{C}\right.$ day per leaf) (Martins et al., 2012), as well as for annual crops such as watermelon $\left(23.4^{\circ} \mathrm{C}\right.$ day per node) (Lucas et al., 2012) and eggplant $\left(24.7^{\circ} \mathrm{C}\right.$ day per leaf) (Maldaner et al., 2009).

Phyllochron mean values for the different sowing dates (Table 3) was lower and, consequently, the development rate was higher in E1, and lower for E2, E5 and E10, indicating that the plants develop better 

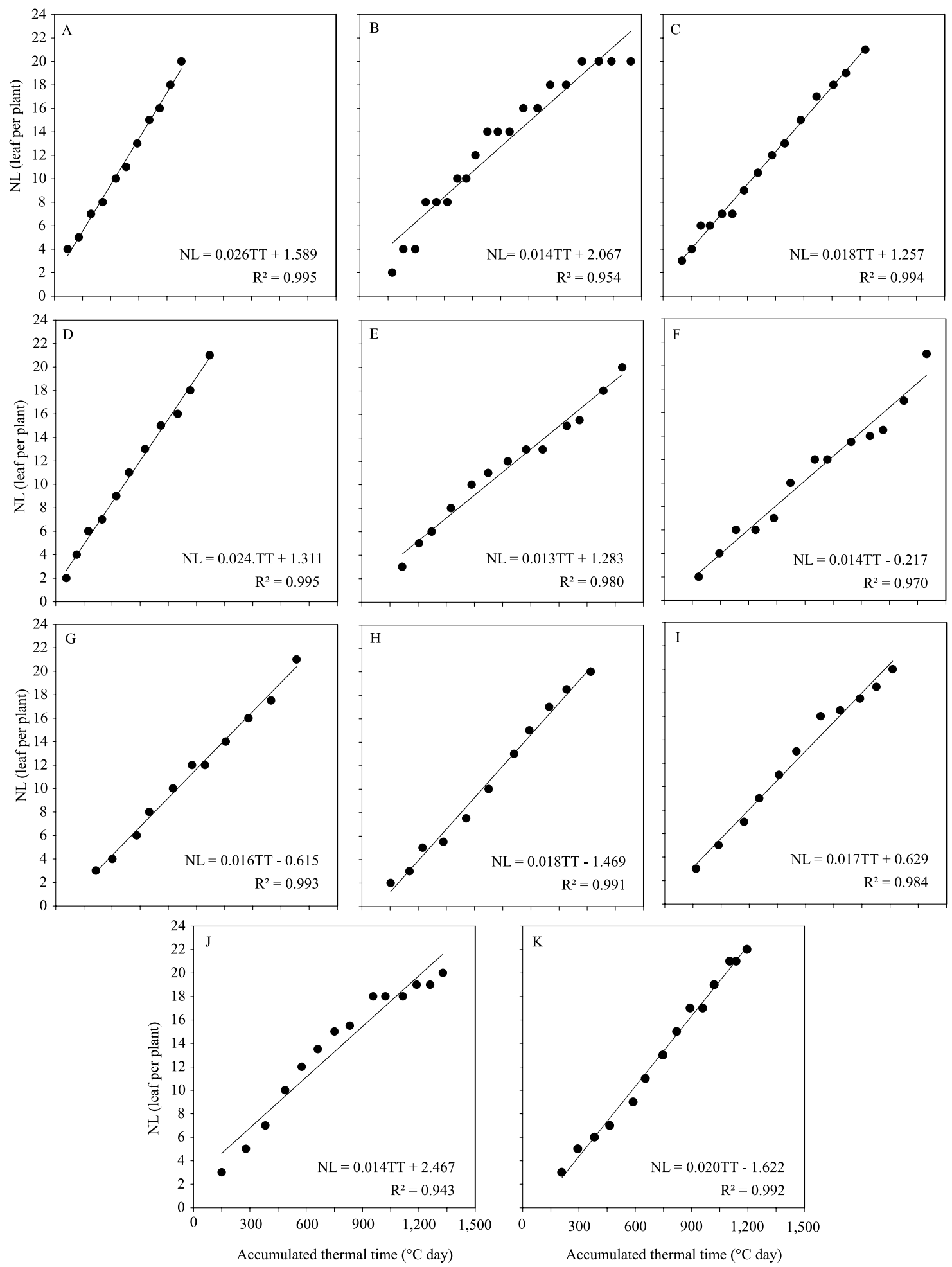

Figure 2. Relationship between the number of accumulated leaves in the main stem (NL) and the accumulated thermal time from the emergence (ATT), used for the phyllochron estimation of Corymbia citriodora seedlings, in the following sowing dates: A, E1; B, E2; C, E3; D, E4; E, E5; F, E6; G, E7; H, E8; I, E9; J, E10; and K, E11. Data are representative of a single experimental unit (NL obtained by the arithmetic mean in this experimental unit), in each sowing date. 

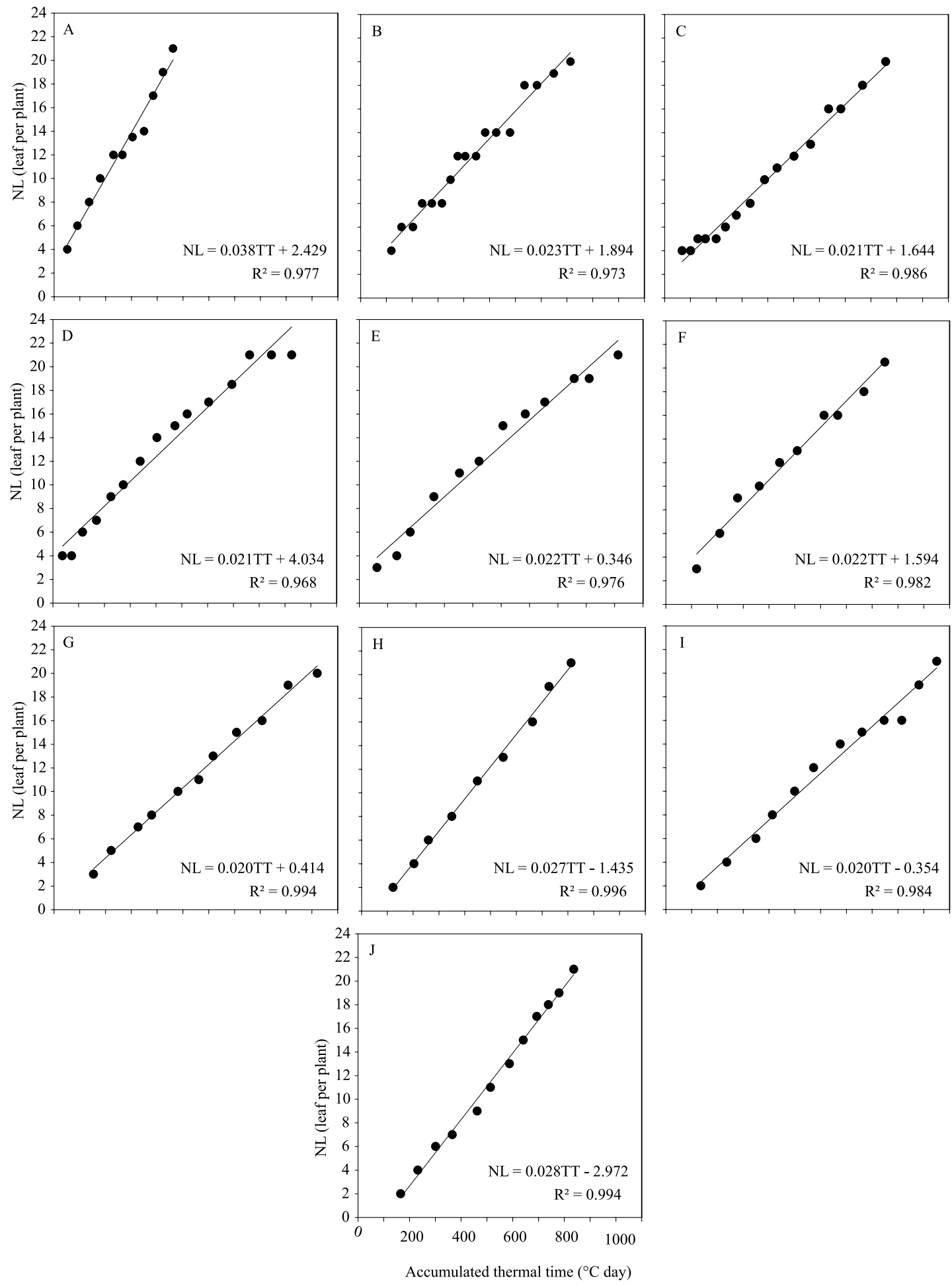

Figure 3. Relationship between the number of accumulated leaves in the main stem (NL) and the accumulated thermal time (TT) from the emergence used for the phyllochron estimation of Eucalyptus urophylla seedlings, in the following sowing dates: A, E1; B, E2; C, E3; D, E4; E, E5; F, E6; G, E7; H, E8; I, E9; and J, E11. Data are representative of a single experimental unit (NL obtained by the arithmetic mean of the experimental unit), in each sowing date. 
under the temperature and meteorological conditions observed during E1. Thus, the optimum temperature was $17.1^{\circ} \mathrm{C}$, determined by the arithmetic mean of the average temperatures for the sowing date with the greatest vegetative development (Lisboa et al., 2012), for both species. These values are biologically realistic and resemble those found for photosynthesis (10.0 to $15.0^{\circ} \mathrm{C}$ ) and growth $\left(16.0^{\circ} \mathrm{C}\right)$ of E. globulus (Battaglia et al., 1996; Almeida \& Sands, 2016) and P. ponderosa $\left(20.0^{\circ} \mathrm{C}\right)$ (Landsberg et al., 2003) and, also, for the olive cultivars Arbequina $\left(16.1^{\circ} \mathrm{C}\right)$ and $\operatorname{MGS}$ ASC $315\left(14.7^{\circ} \mathrm{C}\right)$ (Lisboa et al., 2012).

Information on the estimation of cardinal temperatures for the seedling phase of forest species is scarce. Nonetheless, such information is very useful to know the most adapted species to the climatic conditions of cultivation (Martins et al., 2012; Souza \& Martins, 2014), as well as to provide planning, management, and crop treatments in field conditions. In addition, these values are constantly used in air temperature functions which make part of development and production models (Soltani \& Sinclair, 2012; Martins et al., 2014; Almeida \& Sands, 2016).

Table 3. Mean values for phyllochron $\left({ }^{\circ} \mathrm{C}\right.$ day per leaf) for the eleven sowing dates of Corymbia citriodora and Eucalyptus urophylla ${ }^{(1)}$.

\begin{tabular}{lc}
\hline Sowing date & Phyllochron $\left({ }^{\circ} \mathrm{C}\right.$ day per leaf $)$ \\
\hline E1 & $32.77 \mathrm{a}$ \\
E2 & $69.50 \mathrm{~d}$ \\
E3 & $47.74 \mathrm{~b}$ \\
E4 & $52.10 \mathrm{~b}$ \\
E5 & $78.98 \mathrm{~d}$ \\
E6 & $62.08 \mathrm{c}$ \\
E7 & $60.63 \mathrm{c}$ \\
E8 & $51.06 \mathrm{~b}$ \\
E9 & $51.26 \mathrm{~b}$ \\
E10 & $71.57 \mathrm{~d}$ \\
E11 & $43.46 \mathrm{~b}$ \\
\hline Average & 55.92
\end{tabular}

(1) Means followed by equal letters do not differ by the Tukey's test, at $5 \%$ probability.

\section{Conclusions}

1. The cardinal temperatures for leaf development of Corymbia citriodora in the seedling phase are 8.7, 17.1, and $41.3^{\circ} \mathrm{C}$, for the base, optimum, and maximum temperatures, respectively; and for Eucalyptus urophylla, these temperatures are 11.5, 17.1, and $40.5^{\circ} \mathrm{C}$, respectively.

2. The average phyllochron of C. citriodora is $62.95^{\circ} \mathrm{C}$ day per leaf, and for E. urophylla it is $46.03^{\circ} \mathrm{C}$ day per leaf.

\section{Acknowledgments}

To Coordenação de Aperfeiçoamento de Pessoal de Nível Superior (Capes, process No. 1115820), for the scholarship granted.

\section{References}

ABREU, M.C.; MARTINS, F.B.; FREITAS, C.H. de; PEREIRA, R.A. de A.; MELLONI, E.G.P. Valores limítrofes para transpiração, desenvolvimento e crescimento de Corymbia citriodora (Hook.) K.D. Hill \& L.A.S. Johnson em resposta à deficiência hídrica no solo. Revista Árvore, v.39, p.841-852, 2015. DOI: 10.1590/010067622015000500007.

ALMEIDA, A.C.; SANDS, P.J. Improving the ability of 3-PG to model the water balance of forest plantations in contrasting environments. Ecohydrology, v.9, p.610-630, 2016. DOI: 10.1002/ eco.1661.

BATtAGlia, M.; BEADlE, C.; LOUGHHEAD, S. Photosynthetic temperature responses on Eucalyptus globulus and Eucalyptus nitens. Tree Physiology, v.16, p.81-89, 1996. DOI: 10.1093/treephys/16.1-2.81.

CALLEJAS, I.J.A.; NEVES, G.A.R.; TAVARES, A. da S.; MOURA, I.B. de; LIMA, E.A. de. Determinação das temperaturas cardinais da manga cultivar Roxa através de simulação computacional utilizando um modelo não linear. Ambiência, v.10, p.97-110, 2014. DOI: 10.5935/ambiencia.2014.01.08.

CHIANG, J.-M.; BROWN, K.J. Improving the budburst phenology subroutine in the forest carbon model PnET. Ecological Modelling, v.205, p.515-526, 2007. DOI: 10.1016/j. ecolmodel.2007.03.013.

ERPEN, L.; STRECK, N.A.; UHLMANN, L.O.; LANGNER, J.A.; WINCK, J.E.M.; GABRIEL, L.F. Estimativa das temperaturas cardinais e modelagem do desenvolvimento vegetativo em batatadoce. Revista Brasileira de Engenharia Agrícola e Ambiental, v.17, p.1230-1238, 2013. DOI: 10.1590/S1415-43662013001100015.

FERREIRA, D.F. Sisvar: a computer statistical analysis system. Ciência e Agrotecnologia, v.35, p.1039-1042, 2011. DOI: 10.1590/ S1413-70542011000600001. 
LAGO, I.; STRECK, N.A.; CARVALHO, M.P. de; FAGUNDES, L.K.; DE PAULA, G.M.; LOPES, S.J. Estimativa da temperatura base do subperíodo emergência - diferenciação da panícula em arroz cultivado e arroz vermelho. Revista Ceres, v.56, p.288-295, 2009.

LANDSBERG, J.J.; WARING, R.H.; COOPS, N.C. Performance of the forest productivity model 3-PG applied to a wide range of forest types. Forest Ecology and Management, v.172, p.199-214, 2003. DOI: 10.1016/S0378-1127(01)00804-0.

LIMA, E.P.; SILVA, E.L. da. Temperatura base, coeficientes de cultura e graus-dia para cafeeiro arábica em fase de implantação. Revista Brasileira de Engenharia Agrícola e Ambiental, v.12, p.266-273, 2008. DOI: 10.1590/S1415-43662008000300007.

LISBOA, P.M.M.; MARTINS, F.B.; ALVARENGA, M.I.N.; VIEIRA NETO, J.; REIS, D. da F. Desenvolvimento vegetativo de duas cultivares de oliveira na fase de muda. Ciência Rural, v.42, p.1556-1562, 2012. DOI: 10.1590/S0103-84782012000900007.

LUCAS, D.D.P.; STRECK, N.A.; BORTOLUZZI, M.P.; TRENTIN, R.; MALDANER, I.C. Temperatura base para emissão de nós e plastocrono de plantas de melancia. Revista Ciência Agronômica, v.42, p.288-292, 2012. DOI: 10.1590/ S1806-66902012000200011.

LUZ, G.L. da; MEDEIROS, S.L.P.; TOMM, G.O.; BIALOZOR, A.; AMARAL, A.D. do; PIVOTO, D. Temperatura base inferior e ciclo de híbridos de canola. Ciência Rural, v.42, p. 1549-1555, 2012. DOI: 10.1590/S0103-84782012000900006.

MALDANER, I.C.; GUSE, F.I.; STRECK, N.A.; HELDWEIN, A.B.; LUCAS, D.D.P.; LOOSE, L.H. Filocrono, área foliar e produtividade de frutos de berinjela conduzidas com uma e duas hastes por planta em estufa plástica. Ciência Rural, v.39, p.671677, 2009. DOI: 10.1590/S0103-84782009005000013.

MARTINS, F.B.; PEREIRA, R.A. de A.; PINHEIRO, M.V.M.; ABREU, M.C. Desenvolvimento foliar em duas cultivares de oliveira estimado por duas categorias de modelos. Revista Brasileira de Meteorologia, v.29, p.505-514, 2014. DOI: 10.1590/0102-778620140020.

MARTINS, F.B.; REIS, D. da F.; PINHEIRO, M.V.M. Temperatura base e filocrono em duas cultivares de oliveira. Ciência Rural, v.43, p.1975-1981, 2012. DOI: 10.1590/S0103-84782012001100011.

MARTINS, F.B.; SILVA, J.C. da; STRECK, N.A. Estimativa da temperatura-base para emissão de folhas e do filocrono em duas espécies de eucalipto na fase de muda. Revista Árvore, v.31, p.373-381, 2007. DOI: 10.1590/S0100-67622007000300002.

MARTINS, F.B.; STRECK, N.A. Aparecimento de folhas em mudas de eucalipto estimado por dois modelos. Pesquisa Agropecuária Brasileira, v.42, p.1091-1100, 2007. DOI: 10.1590/ S0100-204X2007000800005.

MATOS, V.A.T. de; PIVETTA, F.; SOBRINHO, S. de P.; TISSIANI, A.S. de O.; PEREIRA, A.P.M.S.; RAMOS, F.T.; CAMPELO JÚNIOR, J.H. Temperaturas basais e exigência térmica para a maturação de caju. Bioscence Journal, v.30, p.969-977, 2014.

MÜLLER, L.; MANFRON, P.A.; MEDEIROS, S.L.P.; STRECK, N.A.; MITTELMMAN, A.; DOURADO NETO, D.; BANDEIRA, A.H.; MORAIS, K.P. Temperatura base inferior e estacionalidade de produção de genótipos diploides e tetraploides de azevém. Ciência Rural, v.39, p.1343-1348, 2009. DOI: 10.1590/S010384782009005000098

PATON, D.M. Eucalyptus physiology. II. Temperature responses. Australian Journal of Botany, v.28, p.555-566, 1980. DOI: 10.1071/BT9800555.

RIBEIRO, A.C.; GUIMARÃES, P.T.G.; ALVAREZ V., V.H. (Ed.). Recomendações para o uso de corretivos e fertilizantes em Minas Gerais: $5^{\mathrm{a}}$ aproximação. Viçosa: Comissão de Fertilidade do Solo do Estado de Minas Gerais, 1999. 359p.

ROSA, H.T.; WALTER, L.C.; STRECK, N.A.; ALBERTO, C.M. Métodos de soma térmica e datas de semeadura na determinação de filocrono de cultivares de trigo. Pesquisa Agropecuária Brasileira, v.44, p.1374-1382, 2009. DOI: 10.1590/S0100204X2009001100002.

SANDS, P.J.; LANDSBERG, J.J. Parameterisation of 3-PG for plantation grown Eucalyptus globulus. Forest Ecology and Management, v.163, p.273-292, 2002. DOI: 10.1016/S03781127(01)00586-2.

SANTOS, H.G. dos; JACOMINE, P.K.T.; ANJOS, L.H.C. dos; OLIVEIRA, V.A. de; LUMBRERAS, J.F.; COELHO, M.R.; ALMEIDA, J.A. de; CUNHA, T.J.F.; OLIVEIRA, J.B. de. Sistema brasileiro de classificação de solos. 3.ed. rev. e ampl. Brasília: Embrapa, 2013. 353p.

SINCLAIR, T.R.; GILBERT, R.A.; PERDOMO, R.E.; SHINE JUNIOR, J.M.; POWELL, G.; MONTES, G. Sugarcane leaf area development under field conditions in Florida, USA. Field Crops Research, v.88, p.171-178, 2004. DOI: 10.1016/j.fcr.2003.12.005.

SOLTANI, A.; SINCLAIR, T.R. Modeling physiology of crop development, growth and yield. Oxfordshire: CAB Internacional, 2012. 322p. DOI: 10.1079/9781845939700.0000.

SOUZA, P.M.B. de; MARTINS, F.B. Estimativa da temperatura basal inferior para as cultivares de oliveira Grappolo e Maria da fé. Revista Brasileira de Meteorologia, v.29, p.307-313, 2014. DOI: $10.1590 / \mathrm{S} 0102-77862014000200013$.

STRECK, N.A.; LAGO, I.; OLIVEIRA, F.B.; HELDWEIN, A.B.; DE AVILA, L.A.; BOSCO, L.C. Modeling the development of cultivated rice and weedy red rice. American Society of Agricultural and Biological Engineers, v.54, p.371-384, 2011. DOI: $10.13031 / 2013.36234$.

YANG, S.; LOGAN, J.; COFFEY, D.L. Mathematical formulae for calculating the base temperature for growing degree days. Agricultural and Forest Meteorology, v.74, p.61-74, 1995. DOI: 10.1016/0168-1923(94)02185-M.

Received on June 12, 2016 and accepted on November 11, 2016 